\title{
Multinarasi Relief Yeh Pulu Basis Penciptaan Seni Lukis Kontemporer
}

\author{
I Wayan Adnyana ${ }^{1}$,Anak Agung Rai Remawa ${ }^{2}$, Ni Luh Desi In Diana Sari ${ }^{3}$ \\ ${ }^{1}$ Prodi Seni Murni, Fakultas Seni Rupa dan Desain ISI Denpasar \\ ${ }^{2}$ Prodi Desain Interior, Fakultas Seni Rupa dan Desain ISI Denpasar \\ ${ }^{3}$ Prodi Desain Komunikasi Visual, Fakultas Seni Rupa dan Desain ISI Denpasar
}

kun_adnyana@yahoo.com

Kajian ini merupakan skema penelitian terapan, yang bertujuan untuk mengungkap konsep multinarasi relief Yeh Pulu, Bedulu, Gianyar, Bali, sebagai basis penciptaan seni lukis kontemporer. Secara metodologis penelitian ini dilakukan dalam dua tahapan: penelitian lapangan (kajian atas narasi relief) berdasar perspektif ikonologi Panofsky, dan berikutnya penelitian eksperimen terkait penciptaan seni lukis kontemporer berdasar perspektif Sullivan dalam 'art practice as a research', yang menunjuk pada tiga tahap: eksperimen medium, bahasa visual, dan penyusunan konteks yang relevan. Berdasar kajian ikonologi, terutama tahap analisis ikonografi, ditemukan bahwa narasi relief Yeh Pulu bersifat multinarasi, yakni pahatan relief yang memiliki beragam jenis tema cerita, seperti praktik pertanian, berburu, meditasi, pesta, asmara, dan lain-lain. Kemudian konsep multinarasi dalam penciptaan seni lukis kontemporer, menjadi: (a) secara medium menggunakan multiteknik dan medium; (b) bahasa visual, menghadirkan berbagai adegan secara berulang, terpadu dan bahkan terkesan saling berlawanan; (c) konteks yang relevan, dengan memasukan ikon tokok-toko pahlawan dunia pop, seperti superman, superwomen, dan lain-lain. Secara ikonologis, bangunan visual yang mempertemukan adegan multinarasi relief Yeh Pulu dengan narasi kepahlawanan dunia pop, menjadi semakin menguatkan konsep multinarasi dalam membangun pesan kepahlawanan dunia sehari-hari dalam karya seni lukis kontemporer semakin berhasil. Penelitian ini melibatkan: Anak Agung Rai Remawa (pengumpul data), dan Ni Luh Desi In Diana Sari (fotografi dan layout).

Kata kunci: multinarasi, relief Yeh Pulu, ikonologi, multiteknik dan seni lukis kontemporer.

\section{Multiple Narratives of Yeh Pulu Relief: A Basis for the Creation of Contemporary Painting}

This paper serves as an applied research scheme which aims to reveal the concept of multiple narratives of Yeh Pulu Relief, located in Bedulu, Bali, as the basis for the creation of contemporary painting. Methodologically speaking, this study was conducted in two stages: a field research (a field study on the relief narratives) based on Panofsky's perspective on iconology, and an experimental research on the creation of contemporary painting based on Sullivan's 'art practice as a research', which consists of three stages: medium experimentation, visual language depiction, and relevant context preparation. Based on the study of iconology, particularly the stage of iconographic analysis, it was found that Yeh Pulu relief contains multiple narratives in that the sculptural relief has various narrative themes, such as farming, hunting, meditation, feast, romance, and others. The concept of multiple narratives in the creation of contemporary painting has led to: (a) the use of multiple techniques and media; (b) visual language depiction by presenting the scenes repeatedly, where they are clashed one against another and create a contradictory impression; (c) presentation of relevant contexts by incorporating iconic superheroes of the popular world, such as Superman, Superwoman, and others. In terms of the iconology, the visual build that brings together the Yeh Pulu relief's multiple-narrative scenes with the narratives of the popular superheroes reinforces the notion that the concept of multiple narratives in constructing the message of everyday-world heroism in contemporary painting will achieve more success. The contributors of this research also include Anak Agung Rai Remawa (as a data collector) and Ni Luh Desi In Diana Sari (as a photographer and layout designer).

Keywords: multiple narratives, Yeh Pulu relief, iconology, multiple techniques and contemporary painting

Proses Review : 1 - 31 Maret 2018, Dinyatakan Lolos: 10 April 2018 


\section{PENDAHULUAN}

Relief Yeh Pulu, di Bedulu, Gianyar, Bali, dibentuk dari teknik pahat bagal, kasar dan tidak begitu banyak detail rumit. Berbeda dengan pola pahatan relief candi Borobudur dan Prambanan di Jawa Tengah yang halus, tertata, dan rumit. Keunikan pemakaian teknik pahat bagal justru menjadikan relief Yeh Pulu terkesan ekspresif. Baik ekspresif dalam gerak, maupun dalam pelukisan tetumbuhan terkesan menjauh dari stilisasi ragam hias. Medium tebing batu padas yang mengandung renik biji batu berukuran kecil-kecil sebagai landasan pahat, sepertinya memang tidak memungkinkan untuk memakai teknik pahat yang halus. Demikian juga tidak memungkinkan untuk membuat ukiran yang rumit, karena gampang pecah dan rontok. Berbeda dengan medium batu solid pada relief Borobudur atau Prambanan.

Sementara secara visual, pahatan relief Yeh Pulu lebih mengungkap berbagai pragmen naratif, seperti pemikul tuak (sejenis minuman beralkohol tradisional), pengusung pacul (sejenis alat pertanian), pemburu macan, pemikul binatang babi, pesta minum teh, penunggang kuda, dan lain-lain. Keseluruhan adegan yang dibangun berdasar keunikan teknik pahat maupun gaya kebentukan itu menunjuk pada tema sentral yakni kepahlawanan dunia sehari-hari (Adnyana, 2017b: 33). Semua adegan berada di antara pahatan sosok lelaki yang melambaikan tangan (seperti memberi salam) di adegan paling awal, dan kemunculan pahatan tentang Ganesha di paling akhir.

Menurut Kempers (1978: 136-138) relief Yeh Pulu merupakan relief 'figur wayang' bertema tentang kepahlawanan Krisna. Kempers merunutnya dari kisah Krisna muda mengangkat gunung Govardhana, hingga pertarungannya dengan beruang Jambawat. Namun Kempers terlihat tidak konsisten dalam membaca adegan relief yang dipahat di atas tebing batu padas itu. Seperti, ia menyebutkan adegan 'berburu macan' pada buku Ancient Indonesian Art (1959), sebagai binatang macan. Sementara pada buku Monumental Bali (1978) malah disebutkan sebagai binatang beruang, menunjuk pada konstruksi tematik 'beruang Jambawat'.

Kempers juga terlihat tidak cermat dalam penyebutan 'figur wayang' untuk menamai gaya kebentukan dari figur-figur relief yang ada. Gaya kebentukan relief Yeh Pulu secara visual lebih cenderung bersifat real-naturalistik, ketimbang menunjuk pada sesuatu gaya yang dekoratif, seperti penggambaran figur wayang yang pipih. Figurasi manusia dalam berbagai fragmen justru digambarkan seperti nyata, seperti penggambaran perempuan (nenek) yang terlihat sedang membuka daun pintu rumah, penggambaran pangeran sedang mengendarai kuda, dan lain-lain. Proporsi figur manusia bahkan dipahat berukuran tinggi manusia dewasa yang normal.
Pandangan Kempers yang tidak konsisten tersebut, jelas mengindikasikan bahwa narasi yang dipahatkan pada relief Yeh Pulu memungkinkan untuk ditafsir ulang. Tafsir yang dibangun kemudian tentu akan memberi peluang adanya upaya pemaknaan ulang atas konsep narasi dari relief yang dipahat kisaran pertengahan abad ke-14 itu. Pemaknaan ulang yang dimaksud, yakni upaya untuk membangun pemaknaan berdasar landasan teori ikonologi Panofsky (1971), yang menekankan pada telaah berbasis analisis visual. Sehingga kajian yang dilakukan menghasilkan temuan konsep baru atas relief Yeh Pulu. Kemudian, konsep ini akan dijadikan landasan penciptaan kreatif seni lukis kontemporer.

\section{METODE}

Kajian dalam upaya pemaknaan atau tafsir ulang atas relief Yeh Pulu, dilakukan dengan telaah visual berdasar perspektif ikonologi Panofsky (1971: 14), yang menekankan pada tiga tahap analisis: pra-ikonografi, ikonografi dan ikonologi. Ketiga tahap analisis tersebut dilakukan dalam penelitian lapangan melalui teknik observasi langsung terhadap visual relief Yeh Pulu, maupun dokumentasi baik foto dan video. Analisis pra-ikonografi penekanannya pada pembacaan atas objek formal: teknik pahat, gaya kebentukan, dan medium (media) relief. Analisis ikonografi lebih pada eksplorasi tentang gaya figurasi dan narasi. Sementara tahap analisis paling akhir, ikonologi, lebih pada pengungkapan makna, dalam konteks ini tentu mengungkap makna atas bangunan narasi relief Yeh Pulu.

Penemuan makna atas narasi relief Yeh Pulu, akan menjadi landasan penciptaan seni lukis kontemporer. Metode penciptaan berpijak pada pandangan 'art practice as a research' (Sullivan, 2005: 124) yang menekankan penciptaan seni sebagai proses penelitian, dalam konteks penciptaan seni lukis kontemporer ini lebih bersifat eksperimentatif. Metode penciptaan seni menurut Sullivan, terdiri dari tiga tahap: eksperimen medium, bahasa visual, dan penyusunan konteks yang relevan (2005: 124).

Eksperimen medium dilakukan untuk menemukan penggunaan bahan, alat, dan juga teknik spesifik yang nantinya akan dipakai dalam proses penciptaan karya. Bahasa visual lebih bersifat temuan gaya visual, baik itu tentang subjek figurasi, pola stilisasi, dan lain-lain yang membangun karakter visual karya. Penyusunan konteks yang relevan lebih pada eksplorasi subjek visual untuk merangkai tema atau narasi tertentu.

\section{KARAKTER VISUAL RELIEF}

Membaca relief Yeh Pulu berdasar analisis visual pra-ikonografi akan menunjuk pada jenis medium, teknik pahat, dan karakter pahatan. Medium yang dipakai landasan penciptaan karya relief adalah tebing batu padas, yang memiliki kandungan butir-butir batu hitam solid 


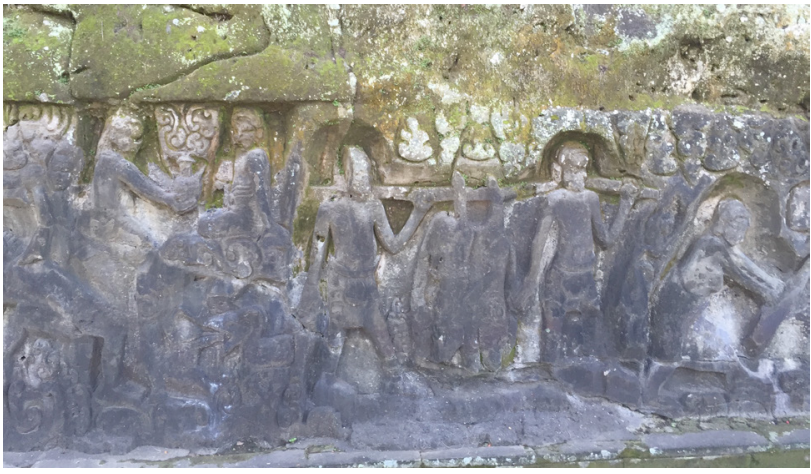

Gambar 1. Multinarasi relief Yeh Pulu: adegan pesta minum (teh), menjinjing hasil buruan (babi hutan), perempuan menarik ekor kuda, berburu macan, dan lain-lain.

Foto oleh I Wayan Adnyana.

yang renik. Memahat pada dinding tebing, dengan karakter medium batu padas yang terjal tentu tidak mudah. Artinya, pemahat menentukan posisi maupun cara memahat dengan menyesuaikan terhadap medium yang ada.

Karakteristik medium juga mempengaruhi alat yang dipakai memahat, termasuk kemudian teknik pahat yang digunakan. Analisis penentuan teknik pahat, tentu bisa dilacak dari karakter pahatan yang muncul, dan terlihat jelas pada karya relief tersebut. Pada relief Yeh Pulu karakter pahatan terlihat sangat ekspresif, dengan pola-pola bagal yang jauh dari kesan rumit. Karakter ini dihasilkan tentu karena medium tebing berbatu padas tersebut sangat terjal dan mudah rapuh. Sehingga pahatan yang rumit sangat tidak memungkinkan karena sifat mudah rapuh tersebut.

Pola pahat bagal, jelas menunjuk pada pemakaian pahat berukuran permukaan taji yang lebar. Termasuk memungkinkan penggunaan alat bantu sejenis kapak bertungkai panjang untuk membuat pola-pola kasar (desain), sebelum kemudian diselesaikan dengan menggunakan pahat. Termasuk juga kalau mencermati kedalaman pahatan relief yang berkisar 30-60 Cm, jelas membutuhkan alat keruk untuk menghasilkan pahatan yang dalam seperti itu.

Kesan yang dimunculkan dari pola pahat yang bagal tersebut menghadirkan figur-figur yang terlihat ekspresif. Menunjuk pada pemahaman 'ekspresionisme' pada konteks seni rupa modern Barat, yang menjelaskan karakter visual yang lebih bertumpu pada upaya mengungkap emosi, luapan batin, dan ekspresi yang bebas (Adnyana, Sudika, In Diana Sari, dan Udayana, 2017: 279).

Karakter permukaan relief yang tidak halus juga menambah kesan ekspresivitas tersebut. Jejak pahatan, terutama pada ceruk kedalaman relief sangat nampak jelas. Berbeda dengan tatahan relief pada candi Borobudur atau Prambanan di Jawa Tengah, yang berpermukaan sangat halus. Artinya relief di kedua candi tersebut pada tahap penyelesaian, melalui proses berupa penggosokan permukaan dengan sejenis amplas halus. Relief Yeh Pulu bisa diduga tanpa melewati proses penyelesaian berupa pengamplasan permukaan pahatan, tetapi hanya dengan penggunaan pahat saja.

Kondisi karakter visual relief yang cenderung kasar, bagal, dan ekspresif tersebut kemudian berpengaruh terhadap gaya figurasi relief. Pada tahap analisis ikonografi, yang di antaranya membahas tentang gaya figurasi, dapat dijelaskan bahwa gaya sangat dipengaruhi oleh karakter visual. Relief Yeh Pulu yang berkarakter permukaan kasar, bagal dan ekspresif, kemudian menunjuk pada gaya visual figurasi real-naturalistik yang cenderung 'impresionistik'. Kemiripan terhadap sosok manusia atau sulur tumbuh-tumbuhan lebih bersifat kemiripan yang 'impresionistik'. Bahwa setiap figur atau sulur tumbuh-tumbuhan yang dipahat dengan mudah bisa mengambil rujukannya ke alam (penciptaan berbasis mimesis; peniruan alam).

Walau tidak kepersisan (peniruan alam) secara real-fotografis, tetapi lebih pada upaya mengungkap kesan, karakter, dan ekspresi. Sementara gaya figurasi real-naturalistik lebih menunjuk pada tema dan konsep narasi yang diungkap. Seperti misalnya, lelaki mengusung tempayan, jelas identik dengan realitas tematik tentang kehidupan petani tuak (minuman beralkohol tradisional Bali). Untuk itulah, analisis ikonografi dan juga ikonologi pada kajian ini, lebih menggali tentang representasi narasi dari relief Yeh Pulu.

\section{MULTINARASI RELIEF YEH PULU}

Membaca narasi (cerita) yang dimunculkan pada relief Yeh Pulu seperti menemukan keberagaman tema. Analisis ikonografi akan mengurai adegan-adegan kemudian secara koheren akan menunjuk makna ikonologis tentang kemultinarasian relief Yeh Pulu.

Adegan-adegan yang dipahat secara berurutan dari awal sampai akhir, dapat dijelaskan mengikuti dua tema besar (di ruang dalam/interior, dan di ruang luar/eksterior). A) tema ruang dalam (interior): figur seorang lelaki sedang berdiri melambaikan sebelah tangan, seorang lelaki pengusung tempayan, seorang perempuan muda (seperti seorang putri), seorang pendeta (proporsi tubuh cebol), perempuan tua sedang membuka daun pintu dari posisi dalam, seorang lelaki pengusung pacul (sejenis alat pertanian), dua orang perempuan (satu duduk dan satunya lagi berdiri) terlihat sedang mendampingi (menunggui) seorang lelaki (berwajah raksasa) yang sedang bertapa. B) tema di ruang luar (eksterior): seorang lelaki sedang mengendarai kuda, tiga lelaki berburu macan, adegan seorang lelaki dan seorang perempuan seperti sedang pesta teh, dua lelaki pemburu mengusung babi hutan, adegan seorang perempuan sedang menarik ekor kuda yang dikendarai seorang laki-laki, dan sosok ganesha. Sebelum kemudian diakhiri dengan pahatan dua bilik ceruk pertapaan, masing-masing berukuran sekitar: lebar 1,5 meter, tinggi 1,3 meter, dan kedalaman sekitar 2 meter. 
Semua adegan pada ruang dalam maupun luar, sangat jelas menunjuk pada keberagaman plot, yang boleh juga dibaca sebagai deretan plot yang berdiri sendiri. Seperti adegan pesta minum (teh), menghadirkan dua sosok (laki-perempuan) yang ditatah di relief bagian atas, antara adegan berburu macan dengan pemikul hasil buruan (babi hutan), jelas merupakan adegan yang berdiri sendiri, karena secara isi narasi sepertinya tidak untuk disambungkan secara paralel dengan adegan lain di sampingnya.

Begitu juga di dalam tema ruang dalam, terdapat adegan lelaki memikul tempayan, kemudian ada sosok perempuan (putri) yang berdiri di tengah, dan seterusnya terdapat adegan pendeta (bertubuh kecil) di bagian bawah, adegan lelaki membawa pacul, dan lain-lain. Artinya, tiap adegan cenderung menghadirkan plot yang berdiri independen. Kesemua adegan lebih menggambarkan keberagaman narasi di dalam dua tema besar: ruang dalam dan ruang luar tadi.

Temuan konsep multinarasi ini tentu menjadi bandingan terhadap pandangan Kempers (1978: 136-138), yang menyebutkan relief Yeh Pulu bertema tunggal, yakni tentang kepahlawanan Krisna. Walau dalam deskripsi, Kempers juga tidak dapat menjelaskan secara utuh setiap adegan merupakan rangkaian yang tidak terpisah dari tema yang dimaksud. Sangat banyak adegan yang tidak terjelaskan, seperti posisi adegan lelaki pengusung tempayan, atau pesta teh, tidak pernah dimunculkan sebagai satu rangkaian cerita tentang Krisna.

Konsep multinarasi lebih mungkin untuk memberi ruang eksis semua adegan, yang memang kadang begitu saja muncul, tanpa kehendak untuk menjadikannya bersambung dengan adegan lain. Tidak seluruh adegan dihadirkan saling menjelaskan. Berbeda halnya dengan relief Prambanan atau Borobudur, setiap adegan dalam satu panel, merupakan adegan yang saling menjelaskan. Tidak jarang ada adegan yang terlihat mengulang, yang sebenarnya untuk menerangkan rangkain gerak dari tema yang diajukan. Seperti kesatria memanah, akan ada banyak kemunculan sosok kesatria itu, sampai benar-benar panah menancap ke sasaran.

Kemultinarasian selain menjelaskan dan menguatkan dua tema besar (ruang dalam dan ruang luar), juga memberi gambaran bahwa relief Yeh Pulu dipahat oleh banyak pemahat. Tiap pemahat menatatah imajinasinya sendiri-sendiri tentang fenomena sosio-budaya era itu. Walau demikian, tentu saja tetap ada dialog di antara pemahat, dan juga dapat diyakini ada pemahat (seniman) yang berfungsi sebagai koordinator, selain bertugas memimpin, juga mediator antar imajinasi yang dipahatkan tersebut. Kemungkinan perannya dalam menentukan pahatan sosok lelaki yang mengacung tangan kanan (tanda memberi salam) sebagai adegan pembuka, dan ganesha sebagai sosok yang dipahat untuk mengakhiri seluruh adegan.
Kemultinarasian relief Yeh Pulu, justru semakin menguatkan tentang konsep 'kepahlawanan sehari-hari dari orangorang biasa' yang ditemukan dalam penelitian sebelumnya (Adnyana 2017b). Karena bagaimana pun esensi kepahlawanan orang-orang biasa, merupakan kepahlwanan dengan praktik yang beragam. Terlebih itu tentang kepahlawanan sehari-hari, sudah pasti menunjuk pada multipraktik hidup.

\section{MULTINARASI SEBAGAI LANDASAN PENCIPTAAN}

Konsep multinarasi yang ditemukan dalam analisis ikonografi maupun ikonologi, kemudian dijadikan landasan praktik penciptaan seni lukis kontemporer. Berikut diurai tiga tahap proses dalam penciptaan yang bertujuan untuk mengaktualisasi konsep multinarasi dalam karya seni lukis yang dimaksud.

Pertama, tahap eksperimen medium, terdiri dari berbagai eksperimen medium yang dipandang selaras dengan upaya penguatan representasi konsep multinarasi relief Yeh Pulu. Eksperimen meliputi berbagai upaya menemukan bahan cat yang memungkinkan munculnya lapis-lapis warna, yang secara imajinatif dapat memunculkan kesan meruang. Eksperimen menentukan cat akrilik walau bersifat menutup (plakat) sesungguhnya dapat diterapkan dengan intensitas pengencer yang sangat cair, sehingga kesan lapis-lapis warna seperti cat air (watercolor) dapat dimunculkan.

Selain penggunaan cat akrilik, medium tinta cina juga tetap dipakai, termasuk juga plototan warna untuk membuat kesan aporisme (tulisan, ungkapan, pernyataan dan lain-lain yang dituliskan menjadi bagian dari representasi lukisan). Medium pensil berwarna putih dan bolpoin gambar juga tetap dipakai, seperti penciptaan 2017.

Eksperimen medium selain menemukan formula bahan juga berkait dengan temuan teknik. Penggunaan medium yang beragam tersebut tentu kemudian menghasilkan multiteknik. Setidaknya terdapat lima macam teknik, yaitu: teknik lelehan cat transparan, teknik cat plakat (dari goresan pisau palet atau kuas), teknik impasto (cat tebal melalui alat plototan), teknik arsir kering (pensil warna putih), dan teknik arsir basah (tinta cina dan bolpoin gambar).

Multiteknik ini diperoleh dari gabungan penerapan berbagai medium pada tiap bidang kanvas. Artinya, pada setiap lukisan dibangun berbasis multimedium dan multiteknik. Sehingga artistik kekontemporeran juga diperoleh dari penggunaan multimedium dan teknik secara serempak di setiap bidang lukisan. Berbeda dengan mazab modernis yang cenderung lebih bertaruh pada mono disiplin teknik pada tiap bidang lukisan.

Kedua, tahap penyusunan bahasa visual, terdiri dari dua 


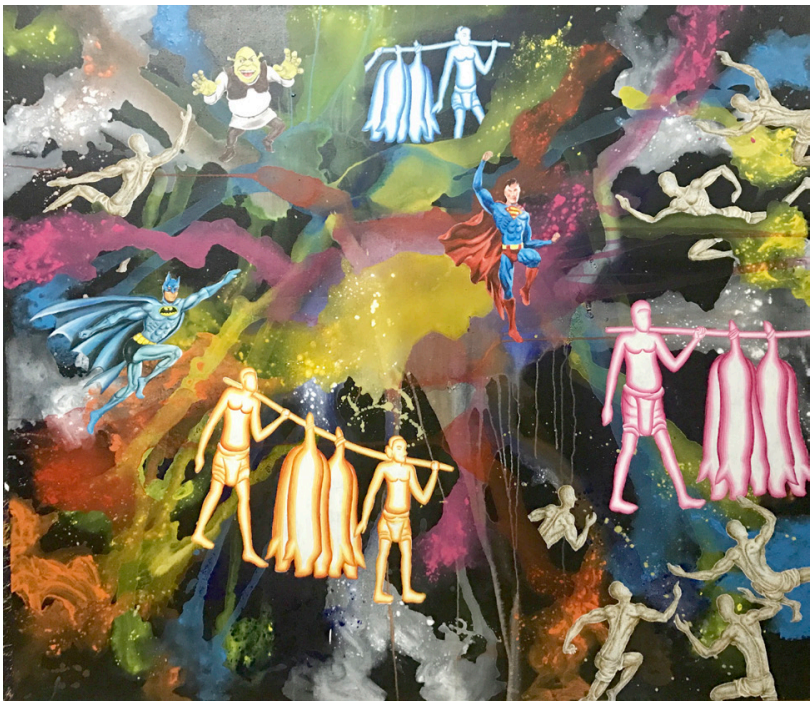

Gambar 2. Lukisan karya I Wayan Adnyana, berjudul 'In Constant Battle' ukuran 140x160 Cm, 2018, medium: akrilik, tinta cina, dan bolpoin gambar (lukisan tahap proses penyelesaian). Foto oleh I Wayan Adnyana.

hal: artistik dan karakter subjek visual. Kedua hal ini kadang hadir berkelindan, padu, dan utuh. Objek utama yang dirujuk tentu kemultinarasian reliefYeh Pulu. Kemultinarasian tersebut diterjemahkan dengan lima pendekatan artistik (temuan proses penciptaan tahun pertama: 2017), yakni: (a) cutting (menggunting; membayangkan relief Yeh Pulu seperti layaknya lembar poster komik, yang kemudian dapat digunting bebas); (b) coloring (memberi warna sesuai kemauan artistik pelukis); (c) highlighting (menjadikan subjek/adegan/plot relief tertentu sebagai pusat perhatian); (d) smashing (merangkai pecahan dan kepingan relief yang berserak akibat korusi bebatuan); (e) drawing (konstruksi subjek visual berbasis gambar/teknik garis) (Adnyana, 2017: 142).

Setiap pendekatan artistik tentu menunjuk pada karakter visual yang spesifik, dan itu akan menjadi unsur bahasa visual. Sementara dalam setiap lukisan boleh jadi hanya terdiri dari satu, atau gabungan berbagai pendekatan artistik. Pendekatan artistik menjadi jalan penemuan bahasa visual berkait dengan subjek plot relief Yeh Pulu.

Proses setelah tahapan perumusan bahasa visual, yakni penentuan konteks yang relevan (Sullivan, 2005: 124). Konteks yang relevan, dihubungkan dengan upaya menyusun kemultinarasian dalam seni lukis dengan objek utama relief Yeh Pulu. Maka ditetapkan upaya memasukkan ikon visual berupa sosok-sosok pahlawan dunia pop, seperti superman, supergirl, batman, dan lain-lain. Hadirnya ikon visual tersebut untuk menegaskan konsep multinarasi, yakni menghubung-sambungkan citra kepahlawanan masa lalu (seperti representasi pahatan relief Yeh Pulu) dengan citra kepahlawanan dunia hiburan populer (yang fiksi).

Ikon visual budaya populer dimasukkan dengan pendekat- an apropriasi estetik, peminjaman ikon visual budaya populer dimasukkan ke dalam visual karya baru. Apropriasi memungkinkan di sana berbagai bentuk dan genre berlangsung dalam konteks silang-budaya, maupun silang-sejarah (Sanders, 2006: 45). Ikon visual 'pahlawan super' dalam budaya populer disandingkan dengan bahasa visual yang telah dirumuskan dari lima pendekatan artistik yang telah ditemukan dalam penelitian sebelumnya (Adnyana, 2017).

Kepahlawanan sehari-hari orang-orang biasa seperti tergambar dalam plot relief Yeh Pulu disandingkan dengan citra kepahlawanan dunia hiburan (film) populer, diharapkan mengguncang imajinasi pelihat. Setidaknya dapat merefleksi sejarah, bahwa untuk menjadi pahlawan tidak semestinya tampil sebagai sosok super, boleh jadi hanya jadi penekun praktik hidup sehari-hari. Atau sebaliknya, akan menjadi renungan, bahwa citra kepahlawanan yang dituju banyak orang justru model kepahlawanan fiksi seperti sosok-sosok super tadi.

Lukisan berjudul 'In Constant Battle' (2018) merepresentasikan tegangan pemahaman dan konsep tentang kepahlawanan tersebut. Menyandingkan adegan dua lelaki sedang memikul hasil buruan (babi hutan) secara repetitif, setidaknya dapat menohok visual kepahlawanan dunia hiburan pop (ala Barat) yang digambarkan hanya pose atau akting. Sementara kepahlawanan sehari-hari yang tergambar pada pahatan relief Yeh Pulu, jelas-jelas menunjukkan hasil. Sedang memikul hasil buruan, berdampingan dengan adegan superman, batman, dan shrek yang sedang berpose, seperti adegan satiristik, yang mengundang keberagaman tafsir.

Secara artistik, lukisan ini menggabungkan berbagai pendekatan, seperti coloring (menggunakan teknik sigarmangsi seperti pewarnaan lukisan klasik Bali) pada petikan adegan relief, drawing (arsiran jelimet) untuk sosok manusia-manusia tanpa nama, dan juga cutting (hanya dengan menggunting satu plot, kemudian dilukis repetitif). Eksplorasi teknik pada lukisan tersebut, meliputi pemakaian teknik tranparan pada lelehan warna (latar belakang karya), teknik plakat pada pewarnaan sosok-sosok pahlawan super, dan teknik arsiran pada figurasi manusia. Sementara tahapan penciptaan tetap menempatkan pelukisan latar belakang dalam tahapan yang pertama, sebagaimana penciptaan sebelumnya (Adnyana, 2017b). Namun tahun ini, berubah dalam hal teknik, yang lebih bertaruh pada lelehan transparan cat akrilik, seperti lazim ditemukan pada teknik cat air. Kemudian baru pelukisan subjek gambar, seteruskan dilakukan penyempurnaan dan penyesuaian baik dengan teknik plakat pisau palet, arsir, atau plototan warna berupa aporisme (coretan berupa pernyataan atau tulisan).

Secara tematik, karya ini merepresentasikan narasi ke tingkat yang lebih kompleks, bahkan boleh disebut sebagai super-multinarasi. Kemultinarasian yang berangkat 
dari berlapis-lapis konsep narasi, baik dari artefak sejarah masa lalu, maupun dari ikon visual budaya populer. Inilah yang kemudian dipahami sebagai ruang kepahlawanan yang tiada akhir. Semua sosok pahlawan dihadirkan secara bersamaan. Manusia seperti merindukan kehadiran pahlawan dalam dunianya sehari-hari, bukan hanya pada peristiwa peperangan bersenjata, yang hanya dimonopoli sosok tentara.

Judul karya 'In Constant Battle' (2018) memberi gambaran, setidaknya pada dua hal: pertama, tentang narasi kepahlawanan yang dihadirkan serempak, antara narasi masa lalu dan masa kini, menegaskan pesan yang kuat bahwa kepahlawan senantiasa menjadi tujuan dan identitas manusia di setiap jaman. Kepahlawanan hadir setiap saat dan dapat diperankan oleh siapa pun. Kedua, pertemuan berbagai entitas estetika di dalam satu karya seni, menjadi kekuatan seni (lukis) kontemporer. Sebuah langgam penciptaan seni yang memberi peluang untuk menjadikan khasanah sejarah masa lalu tidak saja sebagai inspirasi, melainkan sebagai landasan penciptaan kreatif. Artinya, berdasarkan penelitian lapangan yang mendalam, jelajah artefak masa lalu akan sampai pada penemuan-penemuan konsep kreatif yang juga baru. Sehingga penciptaan seni (lukis) kontemporer tidak semata tentang kebebasan dan keluasan pijakan kreatif, tetapi juga pembicaraan tentang intelektualitas seni.

\section{SIMPULAN}

Konsep multinarasi relief Yeh Pulu merupakan kerangka definitif yang menjelaskan tentang keserbanekaan cerita yang dimunculkan dari pahatan relief peninggalan era akhir pemerintahan Bali Kuno. Kemultinarasian dapat dilihat dari adanya berbagai adegan yang menunjuk pada konteks pengisahan yang berdiri sendiri. Walau penelitian sebelumnya (Adnyana, 2017) menjelaskan pola adegan dengan dua tema besar: kepahlawanan di ruang dalam (interior) dan ruang luar (eksterior) sesungguhnya di dalamnya terpahat berbagai adegan yang cenderung dimunculkan untuk mewakili narasi-narasi yang lebih khusus.

Adegan lelaki mengusung tempayan, kemudian disambungkan dengan pahatan sosok seorang putri di sampingnya, tidak sepenuhnya dapat dijelaskan bahwa lelaki itu merupakan pelayan dari putri tersebut. Boleh jadi lelaki pengusung tempayan dihadirkan untuk semata menjelaskan praktik kehidupan sehari-hari pada era relief itu dipahat. Begitu juga pahatan yang menggambarkan tiga lelaki pemburu macan disandingkan dengan pahatan lelaki dan perempuan yang sedang pesta minum teh, juga bukan dua adegan yang secara tegas berkait.

Temuan konsep multinarasi relief Yeh Pulu ini tentu menjadi bandingan dan sandingan atas tafsir yang menyatakan relief tersebut mengambil tema tunggal tentang kehidupan Krisna (Kempers, 1978: 136-138). Kempers dalam pen- jelasannya pun di sana-sini masih mencantumkan (?): tanda tanya, di akhir paragraf, sepertinya ada beberapa hal masih meragukan. Terlihat tidak semua adegan yang terpahat dapat dijelaskan sebagai bagian utuh dari tafsir cerita yang dituliskan Kempers.

Konsep multinarasi akhirnya bisa mewadahi bahwa semua adegan tidak seluruhnya merupakan adegan yang berangkai untuk tujuan menerangkan satu tema besar (tema tunggal). Karena di sana-sini muncul renik-renik adegan yang memang sepertinya dihadirkan untuk mengungkap adegan tersebut secara naturalistik, tidak berkehendak mewakili persepsi pelihat. Seperti adegan dua lelaki pemikul babi hutan (hasil buruan), itu dihadirkan semata untuk mengisahkan kepahlwanan orang-orang biasa dari perjuangan berburu untuk memenuhi kebutuhan hidup. Hal lain yang dapat dijelaskan dari kemultinarasian relief Yeh Pulu adalah tentang proses pemahatan yang cenderung melibatkan sangat banyak pemahat. Setiap tim pemahat atau sub-tim pemahat menghadirkan satu adegan yang khas. Hal tersebut juga dibuktikan dari karakter figur relief yang muncul sangat beragam, termasuk corak pahatan.

Temuan konsep multinarasi, kemudian dijadikan landasan praktik penciptaan seni lukis kontemporer. Salah satu karya yang diciptakan berjudul 'In Constant Battle' (2018), yang menyambungkan ikon visual 'pahlwan super' dunia hiburan populer dengan adegan dua lelaki pemikul babi hutan dari relief Yeh Pulu. Penyandingan ini justru semakin membawa relief Yeh Pulu ke tingkap supermultinarasi, yaitu melipat gandakan konsep kemultinarasian ke tingkatan yang lebih kompleks. Kemultinarasian lintas jaman, dan juga lintas unsur budaya.

Penyandingan ikon budaya populer dilakukan dengan pendekatan apropriasi, yakni peminjaman ikon visual yang sudah lumrah hadir di ruang publik, baik berupa film animasi, karya kartun, poster, dan lain-lain. Pendekatan apropriasi ini juga semakin menjelaskan tentang kekontemporeran seni lukis yang diciptakan. Selain tentu saja adanya upaya sistematis untuk mengungkap temuan konsep multinarasi sebagai basis penciptaan.

Sebagai penutup, perlu diterangkan bahwa kajian ini merupakan bagian luaran dari skema Penelitian, Penciptaan, dan Penyajian Seni (P3S) tahun kedua (2018) yang didanai Direktorat Riset dan Pengabdian Masyarakat, Direktorat Jenderal Penguatan Riset dan Pengembangan, Kementerian Riset, Teknologi, dan Perguruan Tinggi, di Jakarta. Ucapan terimakasih disampaikan kepada pihak yang mendanai penelitian ini, sehingga penelitian dalam berjalan lancar. 


\section{DAFTAR RUJUKAN}

Adnyana, I Wayan. 2017, “Creative Contemporary Painting: Based on Iconography of Yeh Pulu Relief', proceeding of the $2^{\text {nd }}$ Annual of International Interdisciplinary Conference of Arts Creative and Studies (IICACS) (14-15 October 2017), Kurniawan (editor), Institut Seni Indonesia Surakarta, Surakarta, (http://repo.isi-dps.ac.id/2454/).

Adnyana, I Wayan. 2017b, Ikonografi Kepahlawanan Relief Yeh Pulu (Penelitian, Penciptaan, dan Penyajian Seni Lukis Kontemporer): Buku Ajar, Penerbit Arti, Denpasar.

Adnyana, I Wayan, I Nengah Sudika Negara, Ni Luh Desi In Diana Sari, dan A.A. Gde Bagus Udayana. 2017. "Exploring Yeh Pulu Relief (An Iconography Approach)" dalam Mudra: Jurnal Seni Budaya, Volume 32, No 3 September 2017, Pusat Penerbitan ISI Denpasar, Denpasar, (http:// jurnal.isi-dps.ac.id/index.php/mudra/article/view/176).

Kempers, A.J. Bernet. 1959, Ancient Indonesian Art, Cambridge, Harvard University Press, Massachusetts.

1978, Monumental Bali, Van Goor Zonen, Den

Haag.

Panofsky, Erwin. 1971, Studies in Iconology, Icon Edition, Colorado.

Sanders, Julie. 2006, Adaptation and Appropriation: The New Critical Idiom, Routledge, New York.

Sullivan, Graeme. 2005, Art Practice as Research, Sage Publication, London. 